Republic of China. GSA Today, 2008, 18(18), 4-11; doi:10.1130/ GSATG18A.

15. Zhao, J. et al., Spatio-temporal characteristics of strong aftershocks of the $M_{\mathrm{S}} 8.0$ Wenchuan earthquake. Earthquake Sci., 2010, 23(3), 215-221.

16. Xie, C. D. et al., Pattern of stress change and its effect on seismicity rate caused by $M_{\mathrm{S}} 8.0$ Wenchuan earthquake. Sci. China Earth Sci., 2010, 53(9), 1260-1270.

17. Datta, A., Kamal, Triggering of aftershocks of the Japan 2011 Earthquake by Earth tides. Curr. Sci., 2012, 102(5), 792-796.

18. Dieterich, J. H., Nucleation and triggering of earthquake slip: effect of periodic stresses. Tectonophysics, 1987, 144, 127-139.

19. Lockner, D. A. and Beeler, N. M., Premonitory slip and tidal triggering of earthquakes. J. Geophys. Res., 1999, 104(B9), 2013320151.

20. Beeler, N. M. and Lockner, D. A., Why earthquakes correlate weakly with the solid Earth tides: effects of periodic stress on the rate and probability of earthquake occurrence. J. Geophys. Res., 2003, 108(B8), 2391; doi:10.1029/2001JB001518.

21. Laurent, M. et al., Evidence of earthquake triggering by the solid earth tides. Earth Planet. Sci. Lett., 2009, 278(3-4), 0-375.

22. Zhang, P.-Z., Xu, X.-W., Wen, X.-Z. and Ran, Y.-K., Slip rates and recurrence intervals of the Longmen Shan active fault zone, and tectonic implications for the mechanism of the May 12 Wenchuan earthquake, 2008, Sichuan, China. Chin. J. Geophys., 2008, 51(4), 1066-1073; doi:10.3321/j.issn:0001-5733.2008.04.015 (in Chinese with English abstract).

23. Robert, A. et al., Crustal structures in the area of the 2008 Sichuan Earthquake from seismologic and gravimetric data. Tectonophysics, 2010, 205-210.

24. Lu, R.-J., He, D.-F., John, S., Guan, S.-W., Ma, X.-M., Wang, M.J. and Gui, B.-L., The discovery of structural wedges in the central Longmen Mountains front belt and its geometric and kinematic characteristics: Constraints on the dynamical mechanism of uplifting in the southeast margin of Qinghai Tibet Plateau. Earth Sci. Front., 2010, 17(5), 93-105 (in Chinese with English abstract).

ACKNOWLEDGEMENTS. Thanks for providing data of Wenchuan earthquake from Huang. This study was supported by the National Natural Science Foundation of China (Grant Nos.41964001, 41874156) and State Key Laboratory of Earthquake Dynamics (Project No. LED2019B04). We thank the associate editor and the anonymous reviewer for providing numerous comments that significantly improved the manuscript.

Received 19 September 2019; revised accepted 3 January 2020

doi: $10.18520 / \mathrm{cs} / \mathrm{v} 118 / \mathrm{i} 8 / 1286-1292$

\section{Geochemical pathways of fluoride and boron in the alluvial aquifer of the Dwarka river basin, India}

\author{
Raju Thapa ${ }^{1}$, Srimanta Gupta ${ }^{2, *}$ and \\ Harjeet Kaur ${ }^{1}$ \\ ${ }^{1}$ Geo-Meteorological Risks Management Division, \\ National Institute of Disaster Management, Ministry of Home Affairs, \\ New Delhi 110 001, India \\ ${ }^{2}$ Department of Environmental Science, \\ The University of Burdwan, Burdwan 713 104, India
}

Dwarka river basin, situated in the Birbhum district of West Bengal, India is endemic to fluorosis as groundwater contains fluoride as high as $14 \mathrm{mg} / \mathrm{L}$ (permissible limit $1.5 \mathrm{mg} / \mathrm{L}$ ). Co-existence of boron (B) and fluoride $\left(\mathrm{F}^{-1}\right)$ in groundwater, sometimes acts as a tool to predict the source of fluoride. This research was carried out with an objective to identify the geochemical relationship of these two elements and to find out their source(s) in groundwater. pH of groundwater of the study area was mostly neutral to alkaline, $F^{-}$generally ranged from 0.1 to $10.6 \mathrm{mg} / \mathrm{L}$ and boron ranged from 0.01 to $0.5 \mathrm{mg} / \mathrm{L}$. Fluoride and boron showed a strong positive correlation indicating similar source. Fluorapatite observed in sediment samples was considered to be the main source of fluoride. Clay minerals found in the sediment sample were considered to be the most probable source of boron.

Keywords: Birbhum, boron, fluoride, fluoroapatite, groundwater, zeolite.

IN groundwater, occurrence of fluorine $\left(\mathrm{F}^{-}\right)$and boron (B) together has attracted attention because of their effects on human health. Fluoride $\left(\mathrm{F}^{-1}\right)$ bearing minerals such as fluorite, cryolite and fluorapatite are commonly found in granitic rocks ${ }^{1,2}$ which can contaminate groundwater with $\mathrm{F}^{-}$through water-rock interaction. Occurrence of $\mathrm{F}^{-}$has also been reported in secondary rocks such as argillaceous carbonate rocks ${ }^{3}$, loess deposits ${ }^{4}$, flood plain deposits ${ }^{5,6}$. Occurrence of $\mathrm{F}^{-}$bearing minerals in hard rock terrains is well known, but $\mathrm{F}^{-}$dynamics in alluvial terrains is less documented ${ }^{7,8}$. Natural sources of B include both igneous rocks and sedimentary deposits. The main process for the origin of B in groundwater is waterrock interaction in carbonate rocks, bentonites and evaporites, and ion exchange phenomenon of aquifer materials. In soil, B, associated with organically bound clay and mineral-fixed fractions commonly occurs as borates of sodium $(\mathrm{Na})$ and calcium $(\mathrm{Ca})$. In the earth's crust, average concentration of $\mathrm{B}$ is generally $10 \mathrm{ppm}$; its concentration in rocks ranges from $5 \mathrm{ppm}$ in basalts to $100 \mathrm{ppm}$ in shales ${ }^{9}$. Dwarka river basin (DRB) in Birbhum district

*For correspondence. (e-mail: srimantagupta@yahoo.co.in) 


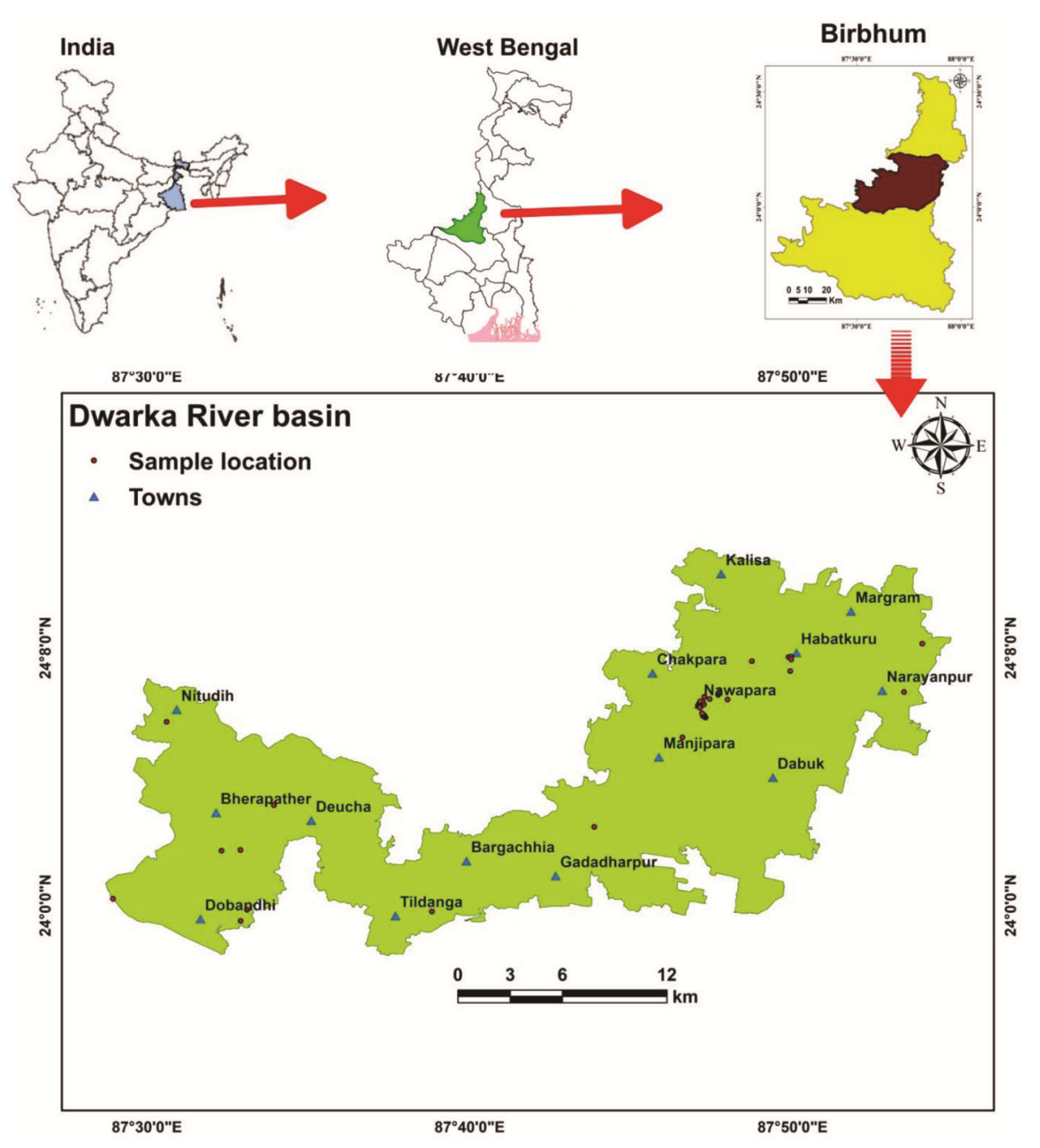

Figure 1. Location map of the study area.

encompasses an area of about 857.773 sq. km with geographical coordinates lying within $23^{\circ} 58^{\prime} 10^{\prime \prime} \mathrm{N}-$ $24^{\circ} 14^{\prime} 12^{\prime \prime} \mathrm{N}$ lat. and $87^{\circ} 28^{\prime} 52^{\prime \prime} \mathrm{E}-24^{\circ} 14^{\prime} 12^{\prime \prime} \mathrm{E}$ long. Spread of the DRB is about $858 \mathrm{sq}$. $\mathrm{km}$ (Survey of India toposheet nos 72P/08, 72P/12, 72P/16, 73M/05, 73M/09 and $73 \mathrm{M} / 13$ ) (Figure 1). The study area is endemic to fluorosis. The main basement rock formation of the basin is the Chottanagpur Gneissic Complex comprising pink granite, granite gneiss with veins of pegmatite and quartz and epidote granite. The Rajmahal Formation occurring in the western part of the study area comprises intertrappean sedimentary rocks and a succession of basaltic flows with the presence of megacrysts of feldspar at the bottom parts. In the eastern part of the basin, hard clay with impregnated caliche nodules (Rampurhat Formation) occurs whereas the central part is mainly covered by laterites extending from north to south ${ }^{10,11}$. Recent sediments occur along the Dwarka river channel. In the southwestern part of the area, from Mollarpur, semi-consolidated Gondwana rocks are known. The subsurface disposition of bedrock and the aquifers in the study area indicate that hard consolidated rocks occur at shallow depth in the western part of the study area and the depth to the bedrock increases from west to east. In the $\mathrm{DRB}, \mathrm{F}^{-}$contamination in groundwater has been reported earlier, but its source and mobilization mechanism has not been addressed so far in the perspective of associated B. The aim of this paper is to highlight the sources of $\mathrm{F}^{-}$and $\mathrm{B}$ anomalies in an alluvial aquifer along with their release mechanisms in groundwater, based on the geochemical study.

In the study area, 40 water samples were collected from 21 villages, namely Phullaipur, Kumardih, Rampur, Sehera, Shrikantapur, Bhagabandh, Kujopara, Kamdebpur, Bilaspur, Murulidanga, Junidpur, Nawapara, Chaktola, Kalidaha, Diyara, Phulidanga, Kalkapur, Habatkuru, Tejhari, Srirampur and Pachanpur (Table 1). pH was measured at the site of collection with a portable $\mathrm{pH}$ meter. Fluoride was measured with ion-selective electrode method and B was measured by inductively coupled plasmamass spectrophotometry (ICP-MS). Three different sites were selected based on the availability of high $\mathrm{F}^{-}$in 
Table 1. Details results of water sample analysis in the study area

\begin{tabular}{|c|c|c|c|c|c|c|c|}
\hline Sample & Name of village & Latitude & Longitude & $\mathrm{pH}$ & $\mathrm{EC}$ & $\mathrm{F}$ & $\mathrm{B}$ \\
\hline 1 & Phullaipur & 23.99766 & 87.55172 & 7.0 & -11.0 & 0.3 & 1.7 \\
\hline 2 & Kumardih & 24.00334 & 87.48254 & 7.4 & -31.0 & 0.1 & 28.3 \\
\hline 3 & Rampur & 24.02864 & 87.54834 & 7.4 & -33.0 & 1.7 & 10.7 \\
\hline 4 & Sehera & 23.99189 & 87.54844 & 7.6 & -42.0 & 1.5 & 3.7 \\
\hline 5 & Shrikantapur & 24.0283 & 87.53857 & 7.5 & -41.0 & 0.8 & 19.5 \\
\hline 6 & Bhagabandh & 24.09502 & 87.51021 & 7.2 & -24.0 & 0.4 & 0.1 \\
\hline 7 & Kujopara & 24.12643 & 87.81244 & 8.0 & -64.0 & 1.7 & 45.4 \\
\hline 8 & Kamdebpur & 24.10895 & 87.79497 & 7.5 & -40.0 & 1.7 & 17.1 \\
\hline 9 & Kamdebpur & 24.1097 & 87.79582 & 7.8 & -57.0 & 2.7 & 15.5 \\
\hline 10 & Kamdebpur & 24.11045 & 87.79582 & 7.7 & -52.0 & 2.7 & 0.1 \\
\hline 11 & Bilaspur & 24.08696 & 87.77661 & 8.1 & -74.0 & 3.5 & 277.7 \\
\hline 12 & Murulidanga & 24.04062 & 87.73105 & 7.5 & -42.0 & 0.3 & 15.6 \\
\hline 13 & Junidpur & 24.09721 & 87.78854 & 8.4 & -92.0 & 0.7 & 47.6 \\
\hline 14 & Junidpur & 24.09766 & 87.78793 & 8.3 & -82.0 & 2.1 & 111.8 \\
\hline 15 & Junidpur & 24.09827 & 87.78793 & 8.5 & -91.0 & 1.7 & 91.5 \\
\hline 16 & Junidpur & 24.09807 & 87.78717 & 8.5 & -95.0 & 3.4 & 118.9 \\
\hline 17 & Junidpur & 24.09887 & 87.78703 & 8.5 & -95.0 & 1.9 & 95.4 \\
\hline 18 & Junidpur & 24.09948 & 87.78673 & 8.4 & -91.0 & 1.0 & 39.4 \\
\hline 19 & Nawapara & 24.10358 & 87.78461 & 8.4 & -89.0 & 2.3 & 421.0 \\
\hline 20 & Nawapara & 24.10435 & 87.7852 & 8.4 & -91.0 & 7.3 & 245.1 \\
\hline 21 & Nawapara & 24.10456 & 87.78707 & 8.5 & -94.0 & 6.8 & 277.5 \\
\hline 22 & Nawapara & 24.10462 & 87.78639 & 8.3 & -84.0 & 2.4 & 131.5 \\
\hline 23 & Nawapara & 24.10367 & 87.78624 & 8.5 & -94.0 & 10.0 & 494.9 \\
\hline 24 & Nawapara & 24.10397 & 87.78568 & 8.6 & -98.0 & 9.8 & 415.4 \\
\hline 25 & Nawapara & 24.10278 & 87.78511 & 8.3 & -85.0 & 4.0 & 151.8 \\
\hline 26 & Nawapara & 24.10239 & 87.78544 & 8.5 & -95.0 & 9.4 & 414.4 \\
\hline 27 & Nawapara & 24.10408 & 87.78773 & 8.5 & -97.0 & 10.6 & 350.7 \\
\hline 28 & Nawapara & 24.10551 & 87.78699 & 8.1 & -77.0 & 1.8 & 83.0 \\
\hline 29 & Nawapara & 24.1056 & 87.78571 & 8.5 & -92.0 & 9.8 & 339.8 \\
\hline 30 & Chaktola & 24.10792 & 87.78791 & 8.2 & -79.0 & 2.0 & 322.7 \\
\hline 31 & Kalidaha & 24.13548 & 87.90041 & 8.0 & -67.0 & 1.8 & 43.7 \\
\hline 32 & Diyara & 24.11043 & 87.89101 & 7.8 & -56.0 & 0.5 & 21.9 \\
\hline 33 & Phulidanga & 24.10659 & 87.79989 & 7.7 & -53.0 & 0.6 & 20.8 \\
\hline 34 & Kalkapur & 24.12132 & 87.83225 & 7.6 & -47.0 & 0.4 & 17.1 \\
\hline 35 & Habatkuru & 24.12857 & 87.83131 & 7.9 & -63.0 & 1.1 & 111.9 \\
\hline 36 & Habatkuru & 24.12876 & 87.83274 & 8.1 & -71.0 & 2.2 & 157.6 \\
\hline 37 & Habatkuru & 24.12729 & 87.8327 & 8.2 & -75.0 & 4.4 & 159.7 \\
\hline 38 & Tejhari & 24.1068 & 87.79065 & 7.9 & -61.0 & 1.2 & 76.1 \\
\hline 39 & Srirampur & 23.99675 & 87.64722 & 8.0 & -70.0 & 0.3 & 22.0 \\
\hline 40 & Pachanpur & 24.05184 & 87.56565 & 7.5 & -42.0 & 0.2 & 5.8 \\
\hline
\end{tabular}

groundwater and depth-wise sediment samples were collected. Field-emission scanning electron microscopy and energy-dispersive X-ray analysis (EPMA, FESEMEDX and XRD) were performed on the collected sediment samples.

The $\mathrm{pH}$ of the groundwater of the study area was generally alkaline (range 7-8.56; mean 8.02). Approximately, $7.5 \%$ of the total number of samples had $\mathrm{pH}$ outside the range permissible for drinking water (6.5 to 8.5; WHO, 2011). The $\mathrm{F}^{-}$concentration in the groundwater ranged from 0.1 to $10.6 \mathrm{mg} / \mathrm{L}$, and approximately $37.5 \%$ of water samples had $\mathrm{F}^{-}<1.5 \mathrm{mg} / \mathrm{L}$, a permissible limit for drinking water. Boron in groundwater ranged from 0.01 to $0.5 \mathrm{mg} / \mathrm{L}$. Pearson's correlation indicated a strong positive correlation between $\mathrm{F}^{-}$with $\mathrm{B}(r=0.70)$ (Figure $\left.2 a\right)$ and moderate positive correlation of $\mathrm{F}^{-}$with $\mathrm{pH}$ $(r=0.41)($ Figure $2 b)$.
Wide variation of $\mathrm{F}^{-}$content in the same alluvium is mainly attributed to the presence or absence of clay layer intercalations within the aquifer. It was noticed that most of the high $\mathrm{F}^{-}$aquifers were intercalated with clay layer having total $\mathrm{F}^{-}$in the range of $70 \mathrm{mg} / \mathrm{kg}$ to $1008 \mathrm{mg} / \mathrm{kg}$ whereas, low $\mathrm{F}^{-}$aquifer within the same alluvium was predominantly made up of thick sand layer.

In alkaline groundwater, the $\mathrm{F}^{-}$present in the fluoridebearing minerals such as fluorapatite, biotite, fluorite, muscovite and soil can be replaced by $\mathrm{OH}^{-}$resulting in higher $\mathrm{F}^{-}$concentrations in groundwater. The most probable mechanisms involved in this are represented in eqs (1-4)

$$
\begin{aligned}
& \mathrm{Ca}_{5}\left(\mathrm{PO}_{4}\right)_{3} \mathrm{~F}+3 \mathrm{H}^{+}=5 \mathrm{Ca}^{2+}+3 \mathrm{HPO}_{4}^{2-}+\mathrm{F}^{-}, \\
& \mathrm{CaF}_{2}+2 \mathrm{OH}^{-}=\mathrm{Ca}(\mathrm{OH})_{2}+2 \mathrm{~F}^{-},
\end{aligned}
$$




$$
\begin{aligned}
\mathrm{KMg}_{3}\left[\mathrm{Al}_{3} \mathrm{Si}_{3} \mathrm{O}_{10}\right] \mathrm{F}_{2}+2 \mathrm{OH}^{-} & \\
= & \mathrm{KMg}_{3}\left[\mathrm{AlSi}_{3} \mathrm{O}_{10}\right]\left[\mathrm{OH}_{2}\right]+2 \mathrm{~F}^{-} \\
\mathrm{KAl}_{2}\left[\mathrm{AlSi}_{3} \mathrm{O}_{10}\right] \mathrm{F}_{2}+ & 2 \mathrm{OH}^{-}=\mathrm{KAl}_{2}\left[\mathrm{AlSi}_{3} \mathrm{O}_{10}\right]\left[\mathrm{OH}_{2}\right]+2 \mathrm{~F}^{-}
\end{aligned}
$$

Total $\mathrm{F}^{-}$in sediments, collected from the study area ranged from $70 \mathrm{mg} / \mathrm{kg}$ to $1008 \mathrm{mg} / \mathrm{kg}$. Clayey sediments were found to have elevated concentration of $\mathrm{F}^{-}$. The results of sequential extraction indicate that the residual form of $\mathrm{F}$ is the most important fraction compared to other forms studied, where, about $80 \%$ of total $\mathrm{F}$ is in residual form. Thus the results of the sequential extraction of $F$ of sediment samples collected from the three different sites showed that the residual form was the most dominant and the decreasing sequence of availability are as follows: residual form $>$ water-soluble $>\mathrm{Fe}-\mathrm{Mn}$ form $>$ organic bounded $>$ carbonate form $>$ exchangeable form.

High $\mathrm{Fe}_{2} \mathrm{O}_{3}(4 \%), \mathrm{MnO}(1 \%)$ and organic matter content of the clay layers also support the crucial role of $\mathrm{Fe}-\mathrm{Mn}$ in releasing $\mathrm{F}^{-}$in groundwater. Boron is strongly absorbed onto natural organic matter which is released into groundwater during microbial decomposition of organic matter. Competitive sorption of $\mathrm{HCO}_{3}$ from the
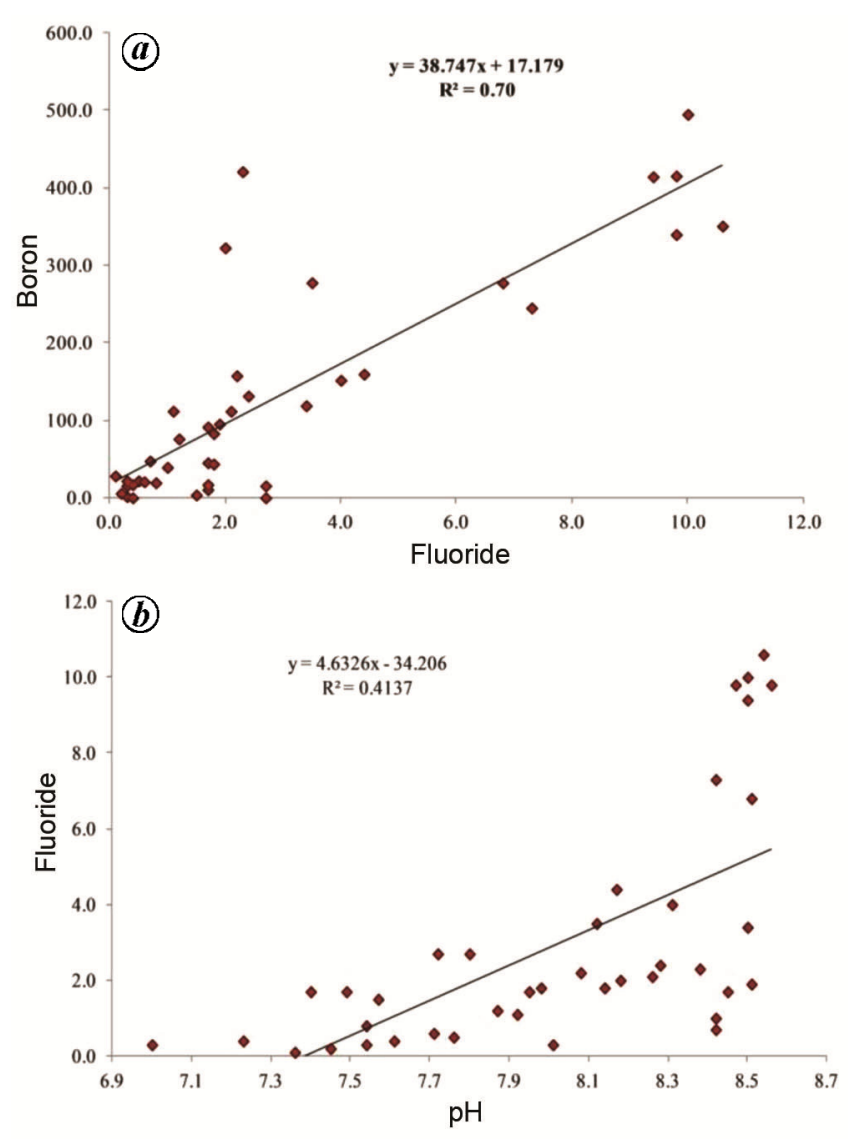

Figure 2. Scatter plot (a) fluoride versus boron (b) fluoride versus $\mathrm{pH}$. surface of ferric oxyhydroxide or clay minerals facilitates desorption of B (ref. 12).

X-ray diffraction (XRD) analysis showed the presence of intercalated zeolitic clay in the sediment samples and was considered to be the most probable source of $\mathrm{F}^{-}$in the study area aquifer ${ }^{13}$. EPMA analysis of the sediment sample revealed the presence of fluorapatite with $\mathrm{F}^{-}$content as high as $5 \mathrm{wt} \%$. Cations such as $\mathrm{Ca}, \mathrm{Na}, \mathrm{K}$ are loosely bound to the framework of zeolites and do not fill the cavities, hence, they can easily replace each other. In aquifer system, B undergoes several interactions which involve processes such as its adsorption and desorption onto clay mineral surfaces which play a crucial role in the mobilization of $\mathrm{B}^{14}$. The zeolitic clay could have been derived from tuffs interbedded with Rajmahal Traps. Apart from geogenic sources, the concentration of $\mathrm{F}^{-}$and $\mathrm{B}$ in groundwater is also influenced by several other factors such as rock-water interaction, residence time of groundwater, $\mathrm{pH}$, etc. ${ }^{15}$.

In the present study, a moderately strong positive correlation $\left(R^{2}=0.7\right)$ was observed between $\mathrm{F}^{-}$and $\mathrm{B}$. Similar observations have also been reported by other researchers ${ }^{15}$.

Boron primarily exists as undissociated boric acid along with some borate ions in natural waters. Since boric acid is a weak acid ( $\mathrm{pKa}$ of 9.15), it usually exists as undissociated boric acid $\left[\mathrm{B}(\mathrm{OH})_{3}\right]$ at neutral to acidic $\mathrm{pH}$ (i.e. $\mathrm{pH}<7$ ) conditions in aqueous solution ${ }^{16}$. With increase in alkalinity of the solution (i.e. $\mathrm{pH}>10$ ), the availability of metaborate anion $\mathrm{B}(\mathrm{OH})_{4}$ increases and becomes the main species in the solution.

Clay minerals are considered to get remarkably bound with $\mathrm{F}^{-}$and $\mathrm{B}$ through ion-exchange and adsorption processes ${ }^{14,17}$. Clay mineral in the aquifer system prolong the residence time of groundwater and changes the water type from $\mathrm{Ca}-\mathrm{HCO}_{3}$ to $\mathrm{Na}-\mathrm{HCO}_{3}$ type and increases the $\mathrm{pH}$ value. Hence the formed alkaline condition favours the leaching of $\mathrm{F}^{-}$and $\mathrm{B}$ in groundwater ${ }^{14}$. Increase in $\mathrm{F}^{-}$ concentration is associated with enhanced B concentration, since these two ions can form stable boron-fluoride ortho-oxy compounds such as $\mathrm{BF}_{3}(\mathrm{OH})$, and on interaction with $\mathrm{Na}$ rich alkaline water, $\mathrm{NaF}$ will become available in groundwater along with $\mathrm{B}$ in the form of boric $\operatorname{acid}^{14}$. The probable mechanism involved here is

$$
2 \mathrm{BF}_{3}(\mathrm{OH})^{-}+4 \mathrm{OH}^{-}+6 \mathrm{Na}^{+} \rightarrow 6 \mathrm{NaF}+2 \mathrm{H}_{3} \mathrm{BO}_{3}
$$

Additionally, $\mathrm{F}^{-}$in groundwater can form several complexes with iron, i.e. $\mathrm{FeF}^{+}$(bivalent) and $\mathrm{FeF}_{2}$ (trivalent), aluminium $\left(\mathrm{AlF}_{n}^{3-n}\right)$, certain organic complexes, etc. ${ }^{13,18}$. From the present study, following observations can be highlighted: (a) About $62.5 \%$ of water samples have $\mathrm{F}^{-}$beyond the permissible limits for drinking water; $\mathrm{B}$ in groundwater ranges from 0.01 to $0.5 \mathrm{mg} / \mathrm{L}$. (b) Strong positive correlation of $\mathrm{F}^{-}$with $\mathrm{B}\left(R^{2}=0.70\right)$. (c) Sequence of $\mathrm{F}^{-}$availability in sediment sample is: residual 
form $>$ water-soluble $>$ Fe-Mn form $>$ organic bounded $>$ carbonate form $>$ exchangeable form. (d) Fe-Mn plays a crucial role in releasing $\mathrm{F}^{-}$in groundwater. (e) Intercalated zeolitic clay in sediment samples could be the main source of $\mathrm{F}$ and $\mathrm{B}$.

Finally, collaborative approaches between government, local NGOs and local people will play a vital role towards successfully implementing water management strategies in the DRB. As majority of the water sources in the study area are affected with $\mathrm{F}^{-}$concentration, an alternative source of water, such as pipeline from uncontaminated surface water resources, rainwater harvesting, watershed management, artificial groundwater recharge, etc. should be considered.

1. Deshmukh, A. N., Shah, K. C. and Sriram, A., Coal ash: a source of fluoride pollution, a case study of Koradi Thermal Power Station, District Nagpur, Maharashtra. Gondwana Geol. Mag., 1995, 9, 21-29.

2. Rao, S., Fluoride in groundwater, Varaha River Basin, Visakhapatnam District, Andhra Pradesh, India. Environ. Monit. Assess., 2009, 152, 47-60.

3. Karro, E., Indermitte, E., Saava, A., Haamer, K. and Marandi, A., Fluoride occurrence in publicly supplied drinking water in Estonia. Environ. Geol., 2006, 50, 389-396.

4. Smedley, P. L. and Kinniburgh, D. G., A review of the source, behaviour and distribution of arsenic in natural waters. Appl. Geochem., 2002, 17(5), 517-568; https://doi.org/10.1016/S08832927(02)00018-5.

5. PHED, Public Health Engineering Department, Government of West Bengal - activities and achievements in rural drinking water supply and other areas. 2007; http://www.wbphed.gov.in/ applications/im/uploads/000643.pdf (accessed on 12 August 2018).

6. Thapa, R., Gupta, S. and Reddy, D. V., Application of geospatial modeling technique in delineation of fluoride contamination zones within Dwarka Basin, Birbhum, India. Geosci. Front., 2017, 8(5), 1105-1114; https://doi.org/10.1016/j.gsf.2016.11.006.

7. Edmunds, W. M. and Smedley, P. L., Fluoride in natural waters. In Essentials of Medical Geology (ed. Selinus, O.), Elsevier Academic Press, London, 2005, pp. 301-329.

8. Thapa, R., Gupta, S. and Kaur, H., Delineation of potential fluoride contamination zones in Birbhum, West Bengal, India, using remote sensing and GIS techniques. Arab. J. Geosci., 2017, 10(527), 1-18; https://doi.org/10.1007/s1251 7-017-3328-y.

9. Woods, W. G., An introduction to boron: history, sources, uses, and chemistry. Environ. Health Perspect., 1994, 102, 5-11.

10. Sen, K. K., Datta, R. K. and Bandopadhaya, S. K., Birbhum coalfield - a major coalfield discovered. Proceedings in National Level Seminar on Coal Resources of India, 1987, pp. 417-427.

11. Sen, K. K. and Vijaya, Palynological study of the Dubrajpur Formation in the Mesozoic Succession, Pachami area, Birbhum coalfield, West Bengal. J. Palaeontol. Soc. Ind., 2005, 50(1), 121-133; http://palaeontologicalsociety.in/vol50_1/v8.pdf

12. Deng, Y., Nordstrom, D. K. and McCleskey, R. B., Fluoride geochemistry of thermal waters in Yellowstone National Park: I. Aqueous fluoride speciation. Geochim. Cosmochim. Acta, 2011, 75(2011), 4476-4489; https://doi.org/10.1016/j.gca.2011.05.028.

13. Thapa, R., Gupta, S., Gupta, A., Reddy, D. V. and Kaur, H., Geochemical and geostatistical appraisal of fluoride contamination: An insight into the Quaternary aquifer. Sci. Total Environ., 2018, 640-641, 406-418; https://doi.org/10.1016/j.scitotenv.2018.05. $\underline{360}$.
14. Uppin, M. and Karro, E., Geological sources of boron and fluoride anomalies in Silurian-Ordovician aquifer system, Estonia. Environ. Earth Sci., 2012, 65, 1147-1156, doi: 10.1007/s12665-011-1363-7.

15. Desbarats, A. J., On elevated fluoride and boron concentrations in groundwaters associated with the Lake Saint-Martin impact structure, Manitoba. Appl. Geochem., 2009, 24(2009), 915-92.7; doi:10.1016/j.apgeochem.2009.02.016.

16. Pennisi, M., Bianchini, G., Muti, A., Kloppmann, W. and Gonfiantini, R., Behaviour of boron and strontium isotopes in groundwater-aquifer interactions in Cornia Plain (Tuscany, Italy). Appl. Geochem., 2006, 21, 1169-1183.

17. Rafique, T., Naseem, S., Bhanger, M. I. and Usmani, T. H., Fluoride ion contamination in the groundwater of Mithi sub-district, the Thar Desert, Pakistan. Environ. Geol., 2008, 56(2), 317-326; doi:10.1007/s00254-007-1167-y.

18. Appelo, C. A. J. and Postma, D., Geochemistry, Groundwater and Pollution, CRC Press, New York, 2005, 2nd edn.

ACKNOWLEDGEMENTS. We are grateful to SERB, India for financial assistance to the project (project no. SB/ES-687/2013 dated 24.03.2015) and also acknowledge DST, Government of India for providing financial support to set-up a sophisticated laboratory in the Department of Environmental Science under FIST programme. We would also like to thank Central Ground Water Board, Survey of India and Geological Survey of India for their help and support.

Received 11 September 2019; revised accepted 8 January 2020

doi: $10.18520 / \mathrm{cs} / \mathrm{v} 118 / \mathrm{i} / 1292-1296$

\section{Financialization and its impact on the nature of knowledge production in bioeconomy}

\section{P. Omkar Nadh*}

Institute for Social and Economic Change, Bengaluru 560 072, India

The growth of medical biotechnology (MBT) globally over the last few decades has brought to light several significant changes in various aspects of society. The most prominent impacts were witnessed in the organization of industrial activity, and the nature of knowledge production. With innovation occupying the centre stage in the creatively destructive economies, financial actors and institutions became important in fuelling innovations. Such dominance of financialization has in turn led to the constitution of several new relationships among various actors and the emergence of a new business culture. This constitution of the 'new' is also a result of the active involvement of the state through a favourable policy environment. In all

*e-mail: omkar@isec.a.cin 